Furcsa Laura

\title{
Szakirodalmi feltárás
}

\section{Témakörök}

- Digitális kompetenciák szerepe az önálló tanulásban, önfejlesztésben

- Digitális kompetenciák szerepe az életben való érvényesülésnél

- Digitális eszközök iskolai alkalmazásának helyzete

- A megcélzott fókuszterületek mentén milyen mérések készültek 2000-től napjainkig (hazai / nemzetközi). 


\section{1 Összefoglaló táblázat}

\begin{tabular}{|c|c|c|c|c|c|}
\hline $\begin{array}{l}\text { Kutatás / } \\
\text { Felmérés } \\
\text { neve }\end{array}$ & $\begin{array}{l}\text { Hatókör } \\
\text { (regionális/ } \\
\text { hazai/ } \\
\text { nemzetközi) }\end{array}$ & $\begin{array}{l}\text { Célközön- } \\
\text { ség (tanár / } \\
\text { tanuló) }\end{array}$ & $\begin{array}{l}\text { Megjele } \\
\text {-nés éve }\end{array}$ & Típusa & $\begin{array}{l}\text { Elérhető, } \\
\text { nyilvános-e a } \\
\text { mérôeszköz }\end{array}$ \\
\hline $\begin{array}{l}\text { Røkenes és } \\
\text { Krumsvik } \\
(2014)\end{array}$ & nemzetközi & tanárképzés & 2014 & $\begin{array}{l}\text { a tanárképzés } \\
\text { IKT-képzés } \\
\text { szempontjá- } \\
\text { ból } \\
\text { szakirodalmi } \\
\text { áttekintés }\end{array}$ & - \\
\hline $\begin{array}{l}\text { Spiteri és } \\
\text { Rundgren } \\
(2017)\end{array}$ & $\begin{array}{l}\text { regionális } \\
\text { (Málta) }\end{array}$ & tanárok & 2017 & $\begin{array}{l}\text { máltai } \\
\text { pedagógusok } \\
\text { digitális } \\
\text { kompetenciá- } \\
\text { jának } \\
\text { vizsgálata }\end{array}$ & $\begin{array}{l}\text { - } \\
\text { (félig } \\
\text { strukturált } \\
\text { interjúkérdé- } \\
\text { sek, néhány } \\
\text { kérdés benne } \\
\text { van a } \\
\text { cikkben) }\end{array}$ \\
\hline $\begin{array}{l}\text { Vázquez és } \\
\text { Montoya } \\
(2015)\end{array}$ & $\begin{array}{l}\text { regionális } \\
\text { (Mexikó) }\end{array}$ & $\begin{array}{l}\text { tanártovább } \\
\text {-képzés }\end{array}$ & 2015 & $\begin{array}{l}\text { MOOC } \\
\text { hatékonyságát } \\
\text { vizsgálták to- } \\
\text { vábbképzésben }\end{array}$ & $\begin{array}{l}\text { (MOOC elötti } \\
\text { és utáni teszt, } \\
\text { interjú) }\end{array}$ \\
\hline $\begin{array}{l}\text { Gudmundsd } \\
\text { ottir és } \\
\text { Hatlevik } \\
(2017)\end{array}$ & $\begin{array}{l}\text { regionális } \\
\text { (Norvégia) }\end{array}$ & tanárok & 2017 & $\begin{array}{l}\text { frissen } \\
\text { végzett } \\
\text { tanárok } \\
\text { digitális } \\
\text { kompetenciá- } \\
\text { ja }\end{array}$ & $\begin{array}{l}\text { igen } \\
\text { (angol } \\
\text { nyelven } \\
\text { megtalálhatók } \\
\text { a kérdöív } \\
\text { kérdései) }\end{array}$ \\
\hline $\begin{array}{l}\text { Fernandez- } \\
\text { Cruz és } \\
\text { Fernandez- } \\
\text { Diaz (2016) }\end{array}$ & $\begin{array}{l}\text { regionális } \\
\text { (Spanyolor- } \\
\text { szág) }\end{array}$ & tanárok & 2016 & $\begin{array}{l}\text { Madridban } \\
\text { dolgozó } \\
\text { tanárok IKT } \\
\text { kompetenciá- } \\
\text { jának } \\
\text { vizsgálata }\end{array}$ & - \\
\hline
\end{tabular}

\section{Friss tanulmányok a pedagógusok digitális kompetenciáiról a nemzetközi pedagógiai szakirodalomban}

Az elmúlt évtizedekben megnövekedett azoknak az empirikus tanulmányoknak a száma, amelyek a tanárképzésben résztvevők digitális technológiai 
felkészültségét vizsgálják, hogyan és milyen szinten képesek információs és technológiai eszközöket (IKT) használni tanításuk során. Ez a szakirodalmi áttekintés azzal a szándékkal készült, hogy áttekintse a legfrissebb pedagógiai cikkeket a pedagógusok digitális kompetenciáiról, különös hangsúllyal az önfejlesztésben betöltött szerepére, illetve a digitális eszközök iskolai alkalmazásának helyzetére.

A digitális kompetencia fogalmát különböző módon lehet definiálni. Kiindulásképpen érdemes a Nemzeti Alaptanterv (2012) definícióját felidézni, miszerint a digitális kompetencia azokat az ismereteket tartalmazza, amelyek a technológia és az általa közvetített tartalmak magabiztos, kritikus, és etikus használatát érintik. A kompetenciához tartozó képességek a megkeresett és az előállított, bemutatott információ feldolgozására és kritikai felhasználására is vonatkoznak, illetve az etikus és felelősségteljes kommunikációs együttmüködés és az interneten történő virtuális csoportokban való részvételre is vonatkozik.

A digitális kompetencia természetesen megtalálható az Európai Unió által nélkülözhetetlennek tartott nyolc kompetencia terület között, hasonlóképpen a digitális kompetencia magában foglalja az IKT eszközök használatát, a forrás- és információkezelési készséget, a kritikus és etikailag megfontolt használatot (Szegedi, 2016). Mivel az itt felsoroltak transzverzális kompetenciák, ezért a digitális kompetencia érinti a matematikai, technológiai kompetenciát is, hiszen a technológia használatát odasorolják. Az Oktatás és képzés 2020 stratégiai keret célja éppen a transzverzális készségek referenciakeretének kidolgozása. Tanulmányunk szempontjából lényeges a tanulás tanulása kompetencia is, mivel az önálló tanulás megszervezése és az új tudás beillesztése a régi ismeretek közé illeszthetö.

Fontos kiemelni, hogy a pedagógusok digitális kompetenciája különbözik a többi foglalkozásban értelmezett digitális kompetenciától. Røkenes és Krumsvik (2014) hangsúlyozza, hogy pedagógusok esetében a digitális kompetencia sokkal többet jelent, mint szoftverek használatának képessége vagy digitális eszközök müködtetése. Több komplex készséget foglal magában (kognitív, motoros, szociológiai és érzelmi készségeket is), amelyek lehetővé teszik a pedagógiai munka hatékony teljesítését digitális környezetben. A pedagógiai folyamatban tisztában kell a tanárnak lennie azzal, hogy az IKT eszközök hogyan változtatják meg az oktatás folyamatát és a tanulási stratégiákra milyen hatást gyakorolnak. Az IKT eszközökkel támogatott tanítás és a digitális tananyagok hatékony használatának ki kell egészíteni a hagyományos tanítási módszereket és szervezési formákat. A módszertani megújulás és az új pedagógiai gyakorlatok elsajátítása pedig magával hozza a folyamatos szakmai fejlődés igényét, elsődlegessé válik ezáltal az egész életen át tartó tanulás, nélkülözhetetlenné válik az önfejlesztés. 
A nemzetközi áttekintés szempontjából lényeges cikk Røkenes és Krumsvik (2014) tanulmánya, amely áttekintést ad a 2000 és 2013 év között online felületen megjelent azon tanulmányokról, amelyeknek vizsgálati fókusza a pedagógusképzésben résztvevők digitális kompetenciája. Kutatásuk során a következő kulcsszavakat használták az áttekintésben részt vevő tanulmányok kiválasztásához: digitális kompetencia + tanár, digitális mủveltség + tanár, számítógépes műveltség + tanár és médiamüveltség + tanár. Tíz országban megjelent 42 cikk felelt meg a feltételeiknek, ezeket kategorizálták és mélyebben elemezték. Nyolc megközelítésmódot azonosítottak szakirodalmi vizsgálatuk során, amelyek mikro- és interaktív szinten azt vették figyelembe, hogy a tanárképzési programok mely elemeket hangsúlyozzák kiemelten:

- Kollaboratív és kooperatív tanulás: itt szinkron és aszinkron online fórumokban, tanulási hálózati csoportokban, interaktív web 2.0 alkalmazásokban, blogokban és egyéb virtuális környezetben történt az innovatív tanulás.

- Metakogníció: ezekben a tanulmányokban a tanárképzésében résztvevőknek reflektálni és kritikailag elemezni kellett, hogy hogyan lehet a különböző technológiai megoldásokat az osztálytermi tanítás során alkalmazni.

- Multimédiás oktatás vagy blended tanulás: az osztálytermi oktatás és az online tanítás kombinációit tekintik át, amelyek az elektronikus médiák széles tárházát használják.

- Modellnyújtás: ezekben a tanulmányokban a tanárképzés oktatói, mentorok és a tanulótársak gyakorlati módszereit elemzik, ahol gyakran sor kerül konkrét szoftver vagy egyéb más technikai módszer bemutatására is.

- Autentikus tanulás: a tanulás valódi élethelyzetekben, a jövendőbeli használat kontextusában történik, miközben felfedezik, létrehozzák és értékelik a résztvevők, hogyan tudják majd a digitális technológiákat használni az osztályteremben.

- Cselekedtető tanulás: a 'learning-by-doing', azaz a megtapasztalás általi, a résztvevőket aktivizáló módszer során bővítik digitális kompetenciájukat.

- Értékelés: ezekben a tanulmányokban a lényeg a különböző technológiai megoldásokon alapuló értékelési módszereken alapul. 
- Elmélet és gyakorlat különbsége: az itt ismertetett cikkek összefoglalják, hogy hogyan próbálják a technológia használatával az elméleti pedagógiai ismeretek és a gyakorlat közötti eltéréseket áthidalni.

A felsorolt területek az elmúlt évek tanárképzésben digitális kompetenciafejlesztés témakörében létrehozott tanulmányainak súlypontjait jelentik, ezért alkalmasak egy elméleti keret kijelölésére.

Spiteri és Rundgren (2017) friss tanulmánya a máltai tanárok digitális kompetenciájára összpontosít. A máltai oktatáspolitikában nagy hangsúlya van a digitális kompetenciának. Az iskolák digitális eszközökkel jól felszereltek, a kutatásban résztvevő tanárok mindegyike használ interaktív táblát és minden pedagógusnak külön laptopja van. Az állami iskolákban négy számítógép van osztálytermenként és BeeBots robotokat használnak. Az egyházi iskolákban pedig saját tablettel rendelkeznek a gyerekek. A máltai tanárok saját online platformmal rendelkeznek (Frontier), amely lehetővé teszi az online kommunikációt kollégák, diákok és szülők között. Spiteri és Rundgren (2017) kutatásában arra kereste a választ, hogy hogyan használják a máltai általános iskolai tanárok a technológiát a gyakorlatban, és hogyan tud a tanárképzés a technológia eredményesebb integrációjához hozzájárulni. Félig strukturált interjúk segítségével vizsgálták meg 26 tanár tapasztalatait és nézeteit. Az eredmények alapján a tanár továbbképzésben még nyomatékosabbnak kell lennie a digitális kompetencia fejlesztésének. Konkrétabban az alábbi nyolc fejlesztendő kategóriát azonosították az interjúk alapján:

- Információkezelés: ismerni kell a keresőprogramok közötti kapcsolatokat és képesnek kell lenni a releváns információk megszürésére. Emellett fontos minden diák bevonása a digitális technológiák használatába, hogy csökkentsék a diákok közötti egyre növekvő digitális különbséget.

- Együttmüködés: a digitális eszközök használatával történő interakció megfelelő használata ne csak a tanár és a szülők között valósuljon meg, hanem az osztályban a diákok között is.

- Kommunikáció és megosztás: a tanulmány szerint a tanárok hajlandók voltak kommunikálni és együttmüködni egymással, viszont nem osztották meg egymással a tartalmakat és a szülőkkel történő online kommunikáció is fejlesztésre szorul.

- Tartalom és tanulási anyagok készítése: annak ellenére, hogy a kutatásban részt vevő összes pedagógus használt digitális technológiát, nem mindenki hozott létre saját maga tanulási anyagokat, különböző formátumú tartalmakat. Ennek okaként az időhiányt, tanárok negatív 
attitüdjét és a kreativitás hiányát jelölték meg, ami azt is jelentheti, hogy a digitális technológiák használata kezd rutinszerüvé válni a pedagógusok között.

- Etikus és felelősségteljes használat: ezt a területet ritkán említették a máltai tanárok, a szerzők szerint ez arra utal, hogy jól ismerik a digitális kompetenciának ezt a dimenzióját, viszont szükség van a folyamatos és naprakész információk átadására.

- Értékelés és problémamegoldás: a résztvevő tanárok tisztában voltak a technológia fontosságával a diákjaik életében és tudták, hogy milyen lehetőséget jelent ez az igény szerinti tanítás szempontjából. Több interakció volt a diákok és a tanárok között az azonnali visszacsatolás miatt. Ez a résztvevő, bevonást elősegítő magatartás segített a diáknak a problémamegoldásban, mivel úgy érezték, jobban kontrollálják saját tanulásukat. A szerzők javasolják, hogy a tanárképzés a tanulási kimenetek értékelésére és a problémamegoldáshoz kapcsolódó készségekre irányuljon.

- Technológiák használata: csak néhány pedagógus kísérletezik új technológiákkal, legtöbben csupán az interaktív tábla használatára hagyatkoznak.

- Kommunikációs módok létrehozása: a máltai tanároknak sikerült a hagyományos kommunikációs módszerek, az írás és olvasás átalakítása új módszerekké (hang, videó és szöveg formátumok). Tisztában vannak vele, hogy a diákok figyelmének megtartása érdekében különböző kommunikációs módokat kell használniuk, és ennek érdekében időt szánnak új módszerek és eszközök kipróbálására.

A fent részletezett nyolc problématerület Spiteri és Rundgren (2017) cikke alapján keretként szolgálhat a tervezett kutatás számára is, hiszen ezek a területek valószínüleg a magyar pedagógusok számára is több nehézséget rejtenek.

A frissen végzett pedagógusok vizsgálata kiváló lehetőséget nyújt arra, hogy következtetéseket lehessen levonni a pedagógusképzés hatékonyságáról és felhívja a figyelmet a szükséges módosításokra. Gudmundsdottir és Hatlevik (2017) kutatásának célja a frissen végzett pedagógusok digitális szakmai kompetenciájának vizsgálata. Kutatásukban megnézték, mit gondolnak a tanárképzés digitális fejlesztési tartalmáról, hogyan készítette fel őket az IKT eszközök használatára a gyakorlatban. 356 frissen végzett tanárt kérdeztek meg kérdőív formájában tapasztalataikról. Röviden, a résztvevők meglehetősen rossz 
minőségü és gyenge hatékonyságú IKT képzésről számoltak be a tanárképzés során.

A tanulmány konceptuális háttere az úgynevezett PDC (professional digital competence) modell, ami a tartalmi, a pedagógiai és a technikai tudás kombinációját jelenti, illetve kiegészül egy sajátos pedagógiai szakmai megközelítésmóddal. A következő három tényezőn alapul:

- általános digitális kompetencia (azok az általános készségek, tudás és attitüdök, amelyek szükséges ahhoz, hogy tanárok, tanárképzők és hallgatók digitális környezetben együtt tudjanak dolgozni);

- tantárgyspecifikus digitális kompetencia az egyes tantárgyak IKT eszközökkel segített oktatásainak egyedi jellemzőit figyelembe véve;

- pedagógus orientált kompetencia, amely a didaktikai tényezőket foglalja magába (pl. az iskola és az otthon közötti kommunikáció, a tanulás pszichoszociális jellemzői stb.) és a tanárok folyamatos önképzését és önálló kutatását.

Az eredmények azt mutatják, hogy a frissen végzett tanárok közel fele az IKT képzés színvonalát alacsonynak tartja, és úgy érzik, digitális kompetenciájuk fejlesztéséhez kevéssé járult hozzá. A résztvevők tisztában vannak az IKT használat előnyeivel és hátrányaival is, és kritikusan reflektálnak saját IKT használatukra a tanítás során. A tanárok $80 \%$ tartja pozitívnak az IKT használatot, azonban közel fele számolt be arról, hogy megzavarta a tanítás folyamatát. Ezért különösen fontos a leendő pedagógusok 'énhatékonyságát' fejleszteni pozitív IKT tapasztalatokkal és hatékonyságnöveléssel, annak érdekében, hogy ebbe a kulcskompetenciába vetett hit pozitívan befolyásolja szakmai munkájukat. A szerzők kiemelik, hogy a tanárképzésben résztvevő oktatók komoly mintaként szolgálnak a jövendőbeli pedagógusok számára, az ő hozzáállásuk és IKT használatuk szoros korrelációt mutatott a kezdő tanárok visszajelzéseivel.

Spanyolországban is végeztek kutatást a pedagógusok digitális kompetenciájának vizsgálatára. Fernandez-Cruz és Fernandez-Diaz (2016) tanulmánya Madridban, 80 iskolában tanító 1433 tanárt vizsgált meg, és arra a következtésre jutottak, hogy lényeges különbség figyelhető meg az optimálisnak tartott IKT készségek között, amelyekre a pedagógusoknak ahhoz van szükségük, hogy képesek legyenek különböző technológiai eszközök használatával hatékony tanítási tevékenységeket kifejleszteni és a pedagógusok valóságban tapasztalt alacsony színvonalú digitális kompetenciája között. A tanulmány lényeges generációs különbségeket talált a tanárok között, akiket a digitális technológiák használatának ideje alapján osztottak be kategóriákba: 
- Y generáció (1977-1994)

- Z Z generáció (1990-es és 2000-es években születettek).

A vizsgálat az UNESCO (2011) szerint javasolt keretrendszer szerint vizsgálta a pedagógusok digitális kompetenciáját, amelyben megjelenik az önképzés szempontja is:

1. általános tantervi szempontok

2. tervezés és értékelés

3. módszertani szempontok

4. IKT használat

5. IKT források kezelése

6. IKT továbbképzés

Ezeket az alosztályokat tekintve alacsony-közepes profilt kaptak a spanyol tanárok. Az általános tantervi szempontok olyan alacsonyak, hogy a legtöbb tanár nem tudja, mit is jelent a digitális kompetencia az oktatásban és hogy ezt hogyan lehetne elérni az osztályteremben. A tanárok osztálytermi stratégiái is szegényes színvonalúak, fooként a komplexitás és a kollaboráció szempontjából. Az IKT használat kiemelkedően alacsony értéke azt jelzi, hogy nincs meg a tanároknak az a biztos technikai tudása, hogy a digitális eszközöket biztonsággal alkalmazzák a tanórákon. Az életkor döntő tényező, nem meglepő módon, a fiatalabb és az informatikát oktatók tanárok voltak a legjobb kompetenciával rendelkezők. Az általános és a középiskolai tanárok között nem találtak lényeges különbséget, ez arra utal, hogy a pedagógusképzés kezdeti szintje kevés hatással van a pedagógusok digitális kompetenciájára. A középiskolai tanárok viszont jobb eredményeket értek el a folyamatos szakmai továbbképzés területén. Azok a tanárok, akik rendelkeznek számítógéppel (PC, laptop, tablet vagy okostelefon) vagy internetkapcsolattal, kedvezőbb IKT használatot jeleztek a tanítás során is. Azok a tanárok, akik pozitív attitüddel rendelkeznek a technológiák felhasználását illetően az oktatásban és meg vannak győződve azok hatékonyságáról, természetesen pozitívabb digitális kompetenciát mutattak. Negatívumként említették a tanárok az IKT eszközöket felhasználó órákra történő hosszabb felkészülési időt.

A spanyol vizsgálat (Fernandez-Cruz és Fernandez-Diaz, 2016) eredményei összhangban vannak Buda András (2011) eredményeivel a magyar pedagógusok jellemzésével az információs társadalomban. Az ő klasszifikációi az IKT eszközök használata és a pedagógus digitális kompetenciájának megfelelően a 
digitális felfedező, a digitális nomád, a digitális vándor, a digitális telepes, a digitális honfoglaló szerepeknek feleltethetők meg. A fejlödés mozgatórugója sokszor a tanulók megváltozott elvárása. Az internetnek köszönhetően a tanári tekintély forrása már nem az ismeretek mélysége, hanem az információk gyors és hatékony elérése. Ennek eszköze a digitális kompetencia, amelynek fejlesztés módja gyakran az önképzés.

A digitális tanulási környezet gyorsan változik, a már meglévő ismeretek elévülése miatt folyamatos tanulásra van szükség a pedagógusoknak, amely megfelel az élethosszig tartó tanulás (lifelong learning) paradigmájának és része a fent részletezett kulcskompetenciáknak. A tanárok önálló tanulása és önfejlesztése nagymértékben függ már meglévő digitális kompetenciájuktól. Ennek egyik módszere a nyílt online kurzus, a MOOC. Vázquez és Montoya (2015) kutatásának célja az volt, hogy megvizsgálják, hogy egy tanárok számára készített MOOC hogyan befolyásolja digitális készségeik fejlődését. A kutatásban 5. és 6. osztályban tanító pedagógusok vettek részt, amelynek része volt egy MOOC elvégzése a tanítási készségek fejlesztéséről digitális környezetben. Az adatgyüjtés módszere pre-teszt és poszt-teszt kérdőív volt, illetve kvalitatív interjúkat is készítettek, hogy a tréning közben tapasztalt problémákat és a tapasztalt pozitív hatásokat megmagyarázzák.

A résztvevő tanárok digitális készségeinek fejlődését vizsgálták meg a következő területeken:

- digitális készségek az információs megoldásban

- lényeges információk kiválasztása a weben

- információkeresés a weben

- információszervezés

- információkezelés

- a megtanult tartalom kommunikálása technológián keresztül

- oktatástechnikai eszközökkel közvetített projekttervezés

- szabadon használható ingyenes tananyagok (OER) használata

- a saját területén OER anyagok beazonosítása

- különböző típusú OER felismerése

- OER jellemzők beazonosítása 
- különböző formátumú ingyenes anyagok tervezése

- különböző formátumú ingyenes anyagok fejlesztése

Az eredmények alapján megállapítható, hogy MOOC használatával lehetséges a digitális készségeket fejleszteni információmegoldás céljából, különösen a kommunikáció és a projekttervezés területén. A résztvevő tanárok technológiával támogatott kommunikációs képessége $15 \%$-kal javult. Ez azt jelzi, hogy jobban ismerik az interneten megtalálható kommunikációs eszközöket, virtuális szakmai közösségekben jobban tudnak együttmüködni, fejlődtek a szociális kapcsolataik, a digitális forrásokat képesek tanítási eszközként és tartalomként integrálni, a pedagógiai kontextusnak megfelelő digitális forrásokat ki tudják választani és értékelni.

Vázquez és Montoya (2015) fontosnak tartotta a szabadon használható ingyenes tananyagok (Open Educational Resources) használatának vizsgálatát, amelyek változatosabbá teszik az oktatást és elősegítik a digitális készségek fejlődését is. A tréning pozitív hatással volt az OER használatra is. A kurzus során elsajátított tudás és képességek a résztvevők számára megelégedéssel szolgáltak, mivel gyakorlati hasznát látták az itt elsajátított ismereteknek.

A MOOC, mint tanulási út, legnagyobb problémái között a magas lemorzsolódási arányt említették meg. Többen nem érzik komfortosnak ezt a környezet, sokan nem tudnak tájékozódni a nagy mennyiségú információban. Az egyik legnagyobb gondot a fogyasztói szemléletü résztvevők okozzák, akik nem vesznek részt a szocializációs tevékenységekben és a hálózatépítésben. A hatékonyság érdekében fontosak a világos célkitüzések és a praktikus használhatóság hangsúlyozása a kurzus kezdetén. 


\section{Felhasznált irodalom}

Fernandez-Cruz, F. J. \& Fernandez-Diaz, M. J. (2016). Generation Z's Teachers and their Digital Skills. Comunicar, 46(XXIV), 97-105.

Buda, A. (2011). Telepesek és nomádok. In: Cser. L. \& Herdon, M. (szerk). Informatika a felsőoktatásban. Debrecen: Debreceni Egyetem, 913-918.

Gudmundsdottir, G. E. \& Hatlevik, O. E. (2017). Digital Competence and Newly Qualified Teachers' Experiences of ICT in Teacher Education Programmes in Norway. European Journal of Teacher Education, I, 117.

Nemzeti Alaptanterv (2012). 110/2012. (VI. 4.) Korm. rendelet

http://net.jogtar.hu/jr/gen/hjegy_doc.cgi?docid=A1200110.KOR

Røkenes, F. M., \& Krumsvik, R. J. (2014). Development of Student Teachers'

Digital Competence in Teacher Education - A Literature Review. Nordic Journal of Digital Literacy, 9(4), 250 - 280.

Spiteri, M. \& Chang Rundgren, S. N. (2017). Maltese primary teachers' digital competence: Implications for continuing professional development. European Journal of Teacher Education, 40(4), 521-534.

Szegedi Eszter (szerk.) (2016). Az európai oktatási szakpolitika prioritásai. Budapest: Tempus Közalapítvány.

UNESCO (2011). UNESCO ICT Competency Framework for Teachers.

http://unesdoc.unesco.org/images/0021/002134/213475e.pdf

Vázquez, N. R. \& Montoya, M. S. (2015). Digital skills development: MOOC as a tool fo teacher training, ICERI2015 Proceedings, 2714-2721. 